\title{
The Pulsed Electron Deposition Technique for Biomedical Applications: A Review
}

\author{
Anna Liguori ${ }^{1}$, Chiara Gualandi ${ }^{1,2}$, Maria Letizia Focarete ${ }^{1,3} \oplus$, Fabio Biscarini ${ }^{4,5}$ and \\ Michele Bianchi ${ }^{4, *}$ \\ 1 Department of Chemistry "Giacomo Ciamician” and INSTM UdR of Bologna, University of Bologna, \\ via Selmi 2, 40126 Bologna, Italy; anna.liguori@unibo.it (A.L.); c.gualandi@unibo.it (C.G.); \\ marialetizia.focarete@unibo.it (M.L.F.) \\ 2 Interdepartmental Center for Industrial Research on Advanced Applications in Mechanical Engineering and \\ Materials Technology, CIRI-MAM, University of Bologna, Viale Risorgimento 2, 40136 Bologna, Italy \\ 3 Health Sciences and Technologies (HST) CIRI, University of Bologna, Via Tolara di Sopra 41/E, \\ Ozzano dell'Emilia, 40064 Bologna, Italy \\ 4 Center for Translational Neurophysiology of Speech and Communication, Istituto Italiano di Tecnologia, \\ via Fossato di Mortara 17-19, 44121 Ferrara, Italy; fabio.biscarini@iit.it \\ 5 Life Science Department, University of Modena and Reggio Emilia, via Campi 103, 41125 Modena, Italy \\ * Correspondence: michele.bianchi@iit.it
}

Received: 11 December 2019; Accepted: 23 December 2019; Published: 25 December 2019

\begin{abstract}
The "pulsed electron deposition" (PED) technique, in which a solid target material is ablated by a fast, high-energy electron beam, was initially developed two decades ago for the deposition of thin films of metal oxides for photovoltaics, spintronics, memories, and superconductivity, and dielectric polymer layers. Recently, PED has been proposed for use in the biomedical field for the fabrication of hard and soft coatings. The first biomedical application was the deposition of low wear zirconium oxide coatings on the bearing components in total joint replacement. Since then, several works have reported the manufacturing and characterization of coatings of hydroxyapatite, calcium phosphate substituted $(\mathrm{CaP})$, biogenic $\mathrm{CaP}$, bioglass, and antibacterial coatings on both hard (metallic or ceramic) and soft (plastic or elastomeric) substrates. Due to the growing interest in PED, the current maturity of the technology and the low cost compared to other commonly used physical vapor deposition techniques, the purpose of this work was to review the principles of operation, the main applications, and the future perspectives of PED technology in medicine.
\end{abstract}

Keywords: pulsed electron deposition; thin films; orthopedic applications; bioactivity; ceramic coatings; yttria-stabilized zirconia; calcium phosphates; hydroxyapatite; biomimetic coatings; antibacterial coatings

\section{Introduction}

In the frame of physical vapor deposition (PVD) techniques, pulsed electron deposition (PED) is a well-established technology to fabricate thin films for photovoltaic, superconductor, and optoelectronic applications [1-7]. PED technology belongs to the family of the channel spark discharges, a type of hollow cathode glow discharge in which a target material is ablated by the local heating induced by an accelerated electron beam $[8,9]$. At the very beginning, this technique was mainly employed for the deposition of both inorganic, i.e., superconductive $\mathrm{MBa}_{2} \mathrm{Cu}_{3} \mathrm{O}_{7-x}$ [10], and organic, i.e., polytetrafluoroethylene (PTFE) [11], thin films.

The modifications introduced by Taliani and coworkers, aimed both at improving the reliability of the technique and at increasing the electron beam density [12,13], identify the transition of the PED 
technology from the traditional channel spark discharge to the pulsed plasma deposition technique (PPD). Similar to the earlier technology, PPD bases on the extraction of electrons from a plasma generated in a rarefied gas through a narrow channel dielectric [14] (Figure 1). The electron beam generation system mainly comprises a hollow cathode connected to the electrical generator, a ring acting as the anode, and a dielectric tube connecting the cathode and the anode and extending beyond the anode [14]. The negative charges of the generated plasma are accelerated, through the application of an up to $20 \mathrm{kV}$ potential difference between the hollow cathode and the anode, and channeled into the dielectric tube in order to reach the target placed at the right opposite end of the tube [14]. The target material impacted by the fast (200-400 ns) pulsed electrons is emitted in the form of a highly ionized plasma, called plasma plume, with the axis perpendicular to the surface of the target. The plasma plume enters in contact with the substrate where the material is, therefore, deposited, forming a film [14].

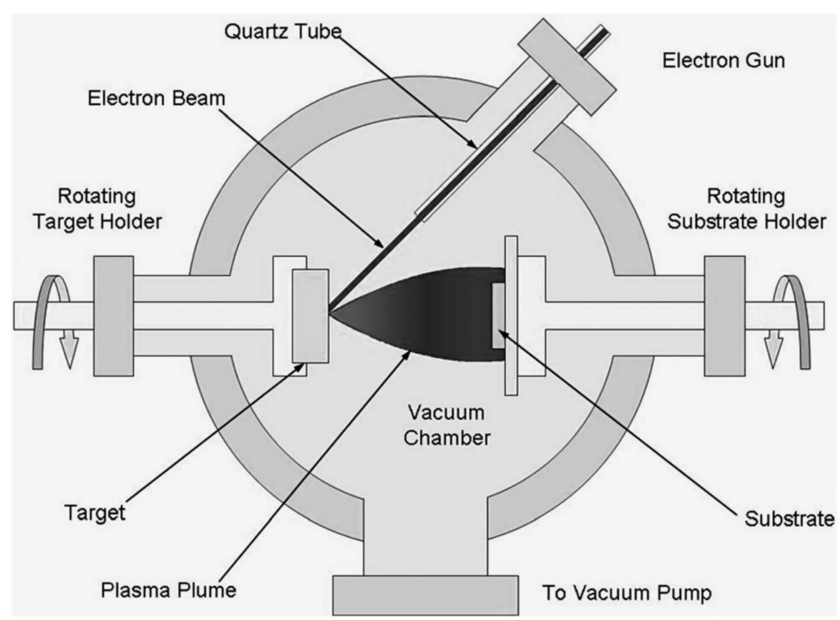

Figure 1. Scheme of the pulsed plasma deposition process, reproduced from [15] with permission from the Royal Society of Chemistry.

Conceptually similar to the widely exploited pulsed laser deposition (PLD), PPD shows additional advantages, mainly due to the replacement of the short pulse of photons in PLD with a short pulse of electrons. Indeed, with respect to PLD, PPD also enables one to process transparent or highly reflective materials and it exhibits higher electrical efficiency (30\%) and lower capital costs [16]. A further advantage of PPD is the possibility to produce films with a controlled stoichiometry of the target, even for complex compounds, such as $\mathrm{La}_{0.7} \mathrm{Sr}_{0.3} \mathrm{MnO}_{3}$ [2]. In the framework of photovoltaic and optoelectronic applications, PPD has been employed for the deposition of a wide range of inorganic thin films, such as tungsten-doped thin oxide [1,4], pyrite [17], and transparent conductive p-type lithium doped [6] and potassium-doped [7] nickel oxide. Efforts have been also devoted to investigating the role of PPD operating conditions (i.e., substrate temperature, electron beam energy) and of the target's characteristics (such as density and composition) on the properties of the deposited coatings [18-20]. Finally, studies have aimed to evaluate the suitability of PPD technology for industrial applications, and concluded that the contextual use of multiple targets together with the active cooling of the electrodes and the target lead to a reduction of the deposition time and to an improvement of the uniformity of the coating's thickness [18,21].

More recently, a PED evolution named ionized jet deposition (IJD), entered the thin film technology market, with the explicit promise of overtaking the main drawbacks of PPD, such as the need for periodically substituting the dielectric tube confining the electron beam till the target surface, and providing, at the same time, superior power and robustness [22]. The IJD working principle is sketched in Figure 2: IJD is based on a pulsed electron source able to generate in vacuum ultra-short electric discharges in the megawatt range (MW) range, produced with a high voltage pulse amplitude up to $25 \mathrm{kV}$ and a duration lower than $1 \mu \mathrm{s}$. The discharge, supported by a gas jet, is directed into a 
solid target through a system of trigger and auxiliary electrodes, generating a superficial explosion with the consequent emission of material in the form of a plasma. The plasma emitted by the target produces on the substrate, a dense coating presenting the same composition of the target [22].

With respect to PPD, IJD is characterized by a higher efficiency $(82 \%-88 \%)$ [22] and leads to a more optimized stoichiometry conservation, turning out to be particularly suitable for: (i) the deposition of superconducting oxides or photoactive semiconductors, (ii) the production of crystalline thin films, and (iii) deposition on any kind of substrate, including thermo-sensitive materials. IJD has been tested for the deposition of SnS thin film layers, useful for photovoltaic applications [23,24]; amorphous chameleon coatings, namely, hard metal carbides and nitrides [25]; and macroscopically homogeneous, adhesive, and cross-linked poly(methylmetacrylate), polystyrene, polyvinylchloride coatings on stainless steel, and glass substrates [26].

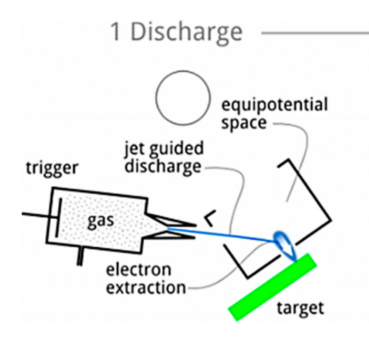

(a)

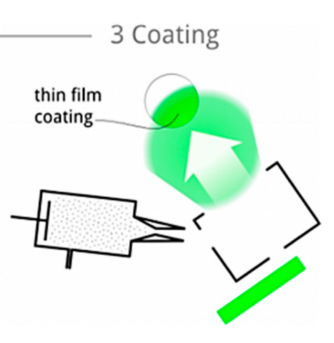

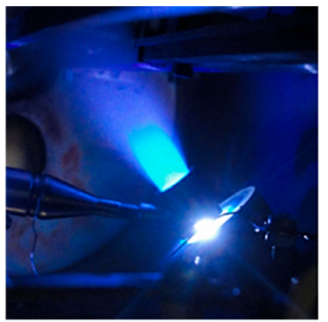

(b)

Figure 2. (a) Scheme of the ionized jet deposition process; (b) system in operation [22].

As briefly summarized, since its introduction, PED has been exclusively exploited to obtain inorganic and organic coatings for photovoltaic or optoelectronic applications. No biomedicine-related applications of this technology were proposed until 2013 [14]. It should be noted that other, more established techniques have been used, since it takes many years to modify the surface of metals and metal alloys by making use of an electron beam [27]; however, due to the very different working principle compared to PED, these techniques will not be discussed within this review.

\section{Scope and Methodology of the Review}

Moved by the continuous demands for innovative yet sustainable approaches to improve the mechanical and biological performances of common implantable materials in orthopedic and dental fields, a number of PVD technologies have been tested over the years to endow the implants with functional coatings, including PLD [28], magnetron sputtering [29], electron beam physical vapor deposition [30], arc ion plating [31], and cathodic arc deposition [32].

In this bio-context, PED has been only recently explored, triggered by the opportunity to obtain well-adhered, nanostructured, and stoichiometric thin films, and coatings on metallic, ceramic, or plastic substrates, along with lower costs for industrial up-scaling compared to competitor techniques. The aim of this work was, thus, to review and discuss the main scientific literature concerning bio-applications of the PED technology, in order to highlight the potentialities and main drawbacks, and point out future directions for the spread of this breakthrough technology in different biomedical sectors.

A systematic search using Google Scholar, Scopus, Web of Science, and Google Patents from 1996 until November 2019 was performed. Principal search strings to filter among the different techniques were: "channel spark discharge", "channel spark ablation", "pulsed plasma deposition", "pulsed electron deposition", "pulsed electron ablation", and "ionized jet deposition". Each of these terms was searched together with one or more of the following terms: "biomedical applications", "ceramic", "(hard) coatings (or thin films)", "load bearing", "articulating surfaces", "orthopedic (or dental) application", "bioactive", "hydroxyapatite", "calcium phosphate", "biogenic", "antibacterial", "antimicrobial", 
and "antiviral". Finally, to find additional papers possibly missed through the database searches, the list of citations from each paper was reviewed.

\section{Hard Ceramic Coatings for Articulating Surfaces in Joint Arthroplasty}

The first reported biomedical application of PED technology is placed in the context of orthopedic prostheses for total joint arthroplasty (TJA) [15]. Nowadays, the vast majority of orthopedic prostheses consist of an ultra-high molecular weight polyethylene (UHMWPE) inlay (or its cross-linked variant, XPE) [33] articulating against a cobalt-chromium or titanium alloy component. Due to osteolysis and aseptic loosening of an implant [34], which is highly correlated to the formation of wear debris associated to the UHMWPE insert [35-37], the average lifetime for a TJA implant is of about 10 years [38]; then, a revision surgery is often required.

PED was formerly used to deposit, at room temperature, crystalline yttria-stabilized zirconia (YSZ) coatings directly on the surface of the UHMWPE inlay, with the aim of preserving it from wear and plastic deformation; thus, increasing the lifetime of the implant overall [15]. In a series of explorative works, micrometric-thick YSZ coatings showing a nanostructured surface texture (Figure 3) were deposited using a PPD setup [15]. YSZ coatings deposited at room temperature exhibited a cubic crystalline phase, conferring high fracture toughness and excellent adhesion to the plastic substrate, despite the significant mechanical mismatch between the harder coating and the softer substrate [15,39]. In addition, nanoindentation tests indicated a much higher strength of normal plastic deformation for YSZ-coated UHMWPE compared to uncoated UHMWPE, along with a drastically reduced creep of the plastic inlay [40]. In the same work, the authors investigated more into detail, the effect of the working gas pressure on the final characteristics of the coatings. Interestingly, they found that the YSZ coatings deposited at a lower working gas pressure (i.e., $5.5 \times 10^{-3} \mathrm{mbar}$ ) were less subjected to plastic deformation than those deposited at a higher pressure (i.e., $8.0 \times 10^{-3} \mathrm{mbar}$ ) [40], due to a higher indentation hardness of the latter.

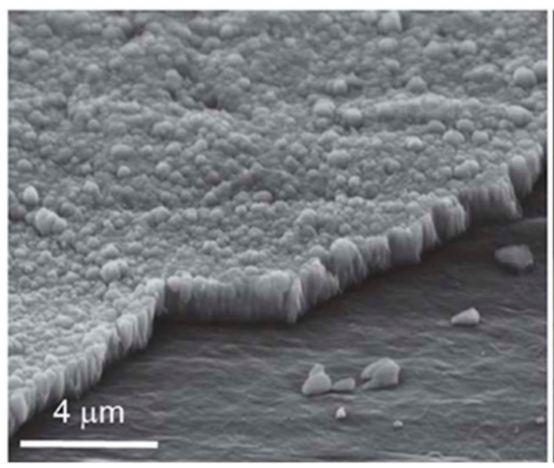

(a)

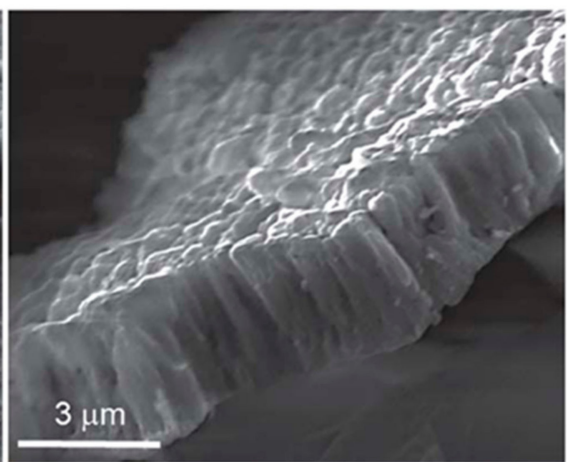

(b)

Figure 3. Scanning electron microscope (SEM) images of yttria-stabilized zirconia (YSZ) coatings deposited on ultra-high molecular weight polyethylene (UHMWPE): (a) microphotograph of a $\approx 1.7 \mu \mathrm{m}$ thick coating; (b) detail of the cross-section of $a \approx 3 \mu \mathrm{m}$ thick coating, reproduced from [15] with permission from the Royal Society of Chemistry.

In a subsequent study, finite element analysis (FEA) was used to determine the optimal coating's thickness in order to minimize UHMWPE strain, crack onset, and stresses at the coating-substrate interface [41]. Both nanoindentation, to simulate the application of high local loads, and micro-indentation tests, to investigate the adhesion of brittle coatings on ductile substrates, were simulated by FEA. The simulations indicated that the local stresses required to promote coating failure strictly depends on its thickness. Specifically, the authors found that thinner coatings $(\approx 0.5 \mu \mathrm{m})$ were more compliant to the applied load compared thicker coatings $(2 \div 4 \mu \mathrm{m})$, as an increase of the thickness led to a decrease of the contact area between the coating and the substrate and an increase 
of the corresponding minimum principal stress (i). The value of the maximum principal stress was instead achieved at the substrate-coating interface; therefore, a stress applied in this region may lead to coating delamination (ii) [41].

PPD has also been tested for depositing YSZ coatings on metal substrates, such as AISI 316-L, titanium, and titanium alloys, to indirectly protect the UHMWPE inlay from wear by coupling it with a low-friction counterpart [42-45]. In a series of papers, where a range of deposition parameters was investigated, the authors reported the possibility to reduce the wear rate of UHMWPE by finely tuning of the working gas pressure [42]. Indeed, gas pressures in the range (4-8) $\times 10^{-3}$ mbar provided low roughness and high thickness coatings on AISI 316-L, capable of ensuring a reduced wear rate and a steady friction coefficient during the tribological test, both under dry and lubricated testing conditions [42]. Along with these results, the deposition of YSZ onto titanium and titanium alloy substrates, carried out with a working pressure of $6 \times 10^{-3}$ mbar, significantly reduced the UHMWPE wear rate [43-45] (17\% and $4 \%$ under dry and lubricated conditions, respectively) of the coated metallic substrate with respect to the uncoated one [43]. This behavior was ascribed to the reduction of the contact area between the polymeric component and the coated metal compared to the uncoated one, strongly limiting the formation of UHMWPE debris, which is related to severe abrasive and adhesive wear at the titanium counter-face $[43,46,47]$.

In a subsequent study, the viabilities of mesenchymal stem cells (MSCs) and pre-osteoblast MC3T3-E1 cells on coated and uncoated titanium substrates [45] were investigated. Cell proliferation increased from day 1 to day 7 for both the samples and the cell types (Figure 4). On day 7, cell proliferation was higher on coated samples than on uncoated ones; further, no changes in the morphology of the nuclei nor abnormal alterations in MSCs and MC3T3 cells seeded on coated samples were detected [45], suggesting that the nanostructured YSZ coatings deposited by PED were non-cytotoxic.

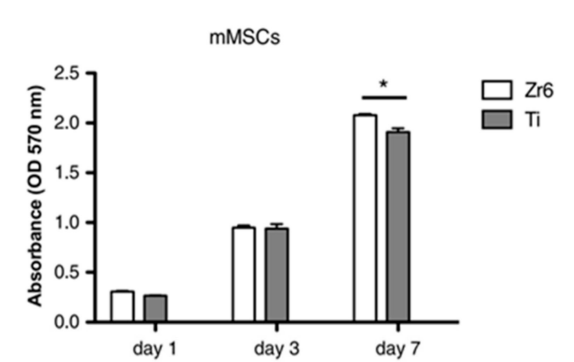

(a)

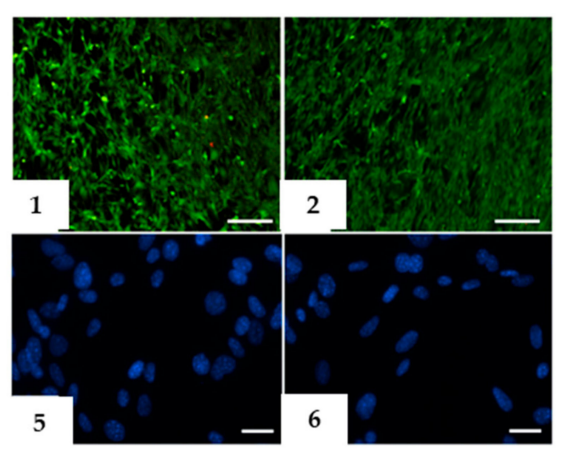

(c)

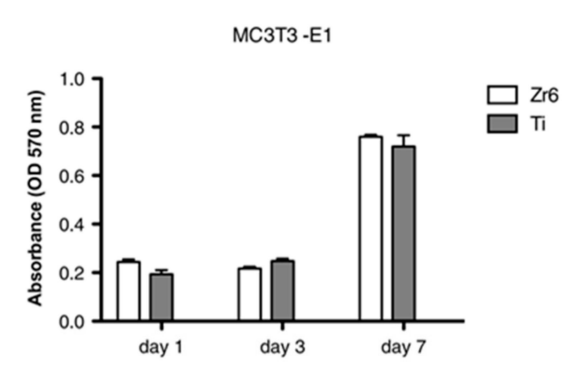

(b)

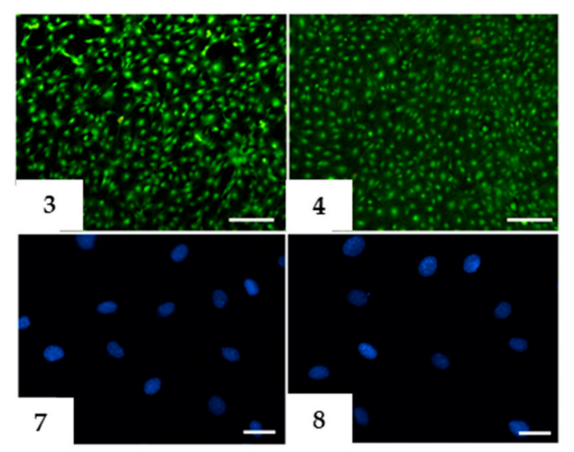

(d)

Figure 4. Analysis of mesenchymal stem cell (MSC) (a) and MC3T3-E1 (b) cell proliferations by MTT assay after 1,3 , and 7 days of seeding on samples; ${ }^{*} p \leq 0.01 ; n=3$. Analysis of cell viability was carried out through live/dead assay $(\mathbf{c}, \mathbf{d})$; calcein AM stains for live cells in green; EthD-1 stains for dead cells in red: (1) and (2) show MSCs; (3) and (4) show MC3T3-E1 seeded on coated and uncoated samples, respectively, after 3 days. Nuclear shape of MSCs $(5,6)$ and MC3T3-E1 $(7,8)$ on coated $(5,7)$ and uncoated $(6,8)$ samples. Zr6 = coated samples; Ti = uncoated samples. Scale bars: $200 \mu \mathrm{m}(1-4)$, $25 \mu \mathrm{m}$ (5-8) [45]. Reprinted with permission from [45]. (C) 2016 Springer Nature. 
In a very recent study, nanostructured YSZ thin films have been deposited by IJD onto different materials (i.e., glass, silicon, titanium, and poly(etheretherketone) (PEEK)), with the aim of investigating the effect of the roughness of the substrate on the microstructure of the growing film. The authors found that, while "smooth" substrates (glass and silicon), did not affect the film roughness, "rough" surfaces (titanium and PEEK) led to homogeneous films well resembling the topography of the substrate [48].

Zirconia-toughened-alumina (ZTA) is a ceramic composite material particularly appealing for dental and orthopedic applications due to its high strength, fracture toughness, elasticity, hardness, and wear resistance $[49,50]$. ZTA thin films were deposited by PPD onto the surface of AISI 420 substrates and showed high adhesion to the substrate, as documented by the relatively high load $(0.8 \mathrm{~N})$ required to achieve the crack onset in the coating during the micro-scratch testing, and the low friction coefficient when tested under lubricated conditions (0.12-0.15) [51]. Further on, X-ray diffraction (XRD) analysis indicated that ZTA coatings exhibited a mixed phase of tetragonal zirconia and $\alpha$-phase alumina embedded in a matrix of amorphous alumina [52].

\section{Bioactive Coatings and Thin Films by PED}

During the last few decades, great effort has been dedicated to improving the integration of orthopedic and dental implants with the surrounding bone tissue (a process named osseointegration) [53-55]. One of the most investigated strategies relies on the coating of the implant surface with materials capable of triggering the biological cascade of events eventually leading to osseointegration (i.e., bioactive materials) [56]. Due to the chemical similarity with the inorganic phase of bone, calcium phosphates $(\mathrm{CaPs})$ and hydroxyapatite (HA) in particular, have been extensively investigated both in vitro and in animal models [57].

In this context, PED technology has been tested for the deposition of nanostructured bioactive thin films on metallic and polymeric implants. In a first study, CaP films were deposited on titanium alloy substrate by ablating a sintered HA target; the analysis of morphology, microstructure and in vitro cytotoxicity were carried out focusing in particular on the effect of the post deposition thermal treatment performed at $600{ }^{\circ} \mathrm{C}$ for $1 \mathrm{~h} \mathrm{[58]}$. The treatment led to crystalline HA and improved the mechanical properties of the film compared to the nearly amorphous as-deposited one, for instance leading to increased elastic strain to failure, resistance to plastic deformation, and adhesion to the substrate. Besides, no significant differences were found in terms of cytotoxicity between as-deposited and treated films, both being capable of subtly promoting adhesion and proliferation of primary osteoblast cells [58].

Among the different implant materials, poly(etheretherketone) (PEEK) is increasingly used as an alternative to metals, especially for spinal fusion, due to excellent resistance to chemicals and sterilization process, and mechanical properties [59-62]. Nevertheless, PEEK totally lacks bioactivity (bioinert material) [63,64]. IJD has been used to deposit strontium doped-hydroxyapatite films on the PEEK substrates with the aim of improving its bioactivity [65]. Strontium ion $\left(\mathrm{Sr}^{2+}\right)$ has been selected as dopant of HA because of its well-known osteogenic effect; i.e., its capability to promote osteoblasts activity (new bone apposition) and inhibit osteoclasts activity (old bone resorption) [66]. Similar to the previously reported study, a two-step approach was adopted. Different $\mathrm{Sr} / \mathrm{Ca}$ molar ratio targets (from 0.04 to 0.20 ) were fabricated and ablated to obtain Sr-HA films with different content of Sr. Energy-dispersive X-ray spectroscopy (EDX) microanalysis confirmed the high degree of fidelity of stoichiometry transfer from the target material to the film. Films were characterized by dense and uniform packing of spherical-like micrometric and submicrometric grains, the size of which ranged mainly from 50 to $100 \mathrm{~nm}$ (Figure 5a,b) [65]. The formation of this nanostructures should be emphasized, since nanotopography plays an important role on promotion of new bone apposition [67]. Noteworthy is that the SrCaP coatings increased the surface roughness (Figure $5 \mathrm{c}$ ) while decreasing the water contact angle (Figure 5d), corresponding to a higher wettability compared to hydrophobic PEEK. This should be remarked on, as the improvement of PEEK surface roughness and wettability is envisioned to promote adhesion, spreading, proliferation, and differentiation of bone cells [68]. 

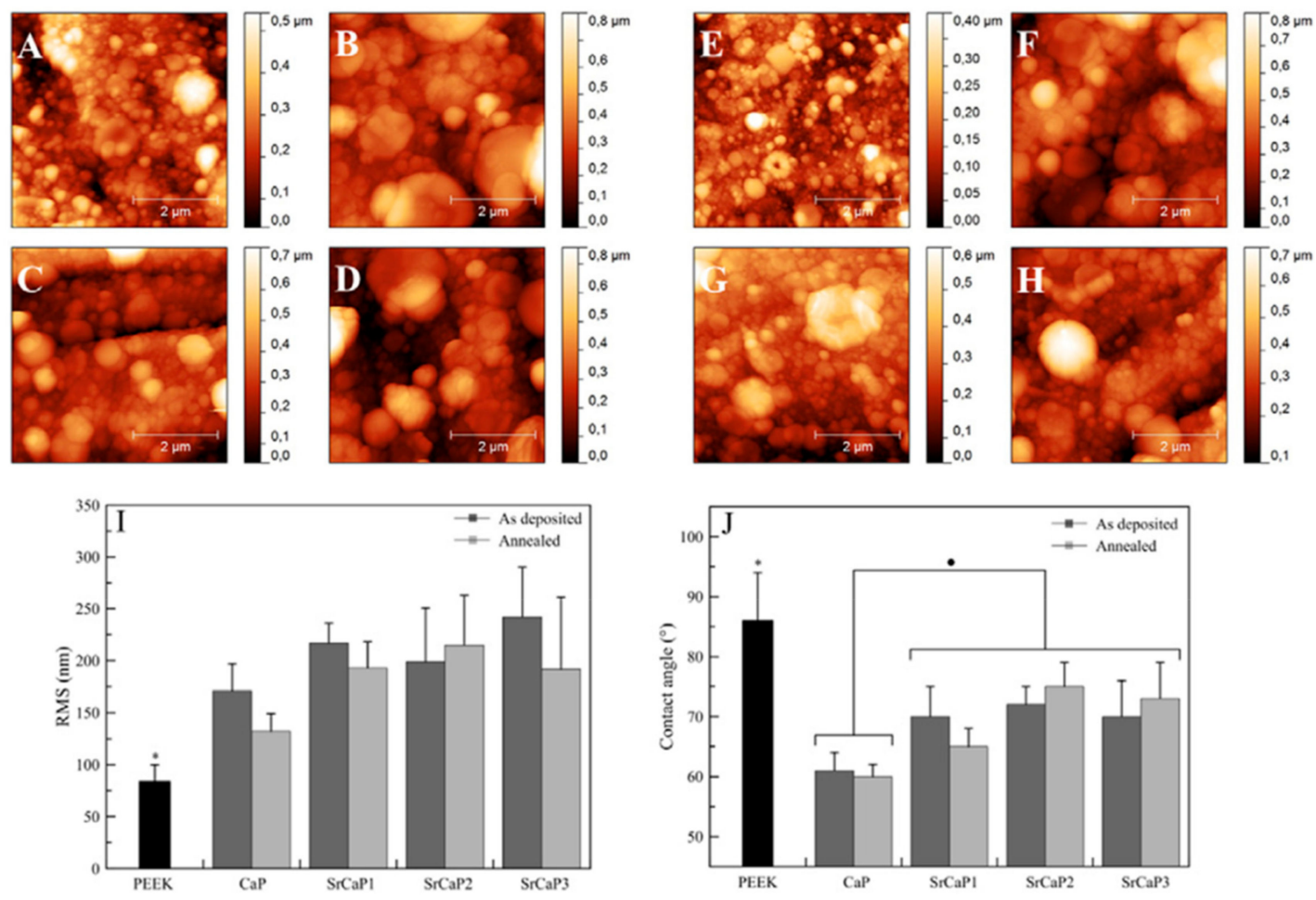

Figure 5. Atomic force microscope (AFM) images of the as-deposited (A-D) and annealed (E-H) coatings; $\mathrm{CaP}\left(\mathrm{Sr}^{2+}\right.$-free coating) (A,E), $\mathrm{SrCaP} 1(\mathrm{Sr} / \mathrm{Ca}$ molar ratio = 0.04) $(\mathbf{B}, \mathbf{F}), \mathrm{SrCaP} 2(\mathrm{Sr} / \mathrm{Ca}$ molar ratio $=0.10)(\mathbf{C}, \mathbf{G})$, and $\mathrm{SrCaP3}(\mathrm{Sr} / \mathrm{Ca}$ molar ratio $=0.20)(\mathbf{D}, \mathbf{H})$. Root Mean Square (RMS) roughness (I) and water contact angle (J) of the bare PEEK, as-deposited, and annealed coatings. Reprinted with permission from [65]. (C) 2017 Elsevier.

In the field of bioactive coatings, biomimetic coatings resembling the composition of natural bone apatite, which is indeed a calcium-deficient, highly-substituted, and poorly crystalline hydroxyapatite [69], are strongly desired, as they are expected to better promote differentiation implant osseointegration compared to highly-crystalline stoichiometric HA or other CaP phases [70-72]. Aiming to fabricate highly biomimetic coatings, bone apatite-like (BAL) thin films were deposited on titanium substrate for the first time by direct ablation of a biogenic source; i.e., a deproteinized bovine bone shaft, by making use of IJD technology $[73,74]$. EDX indicated that the composition of BAL thin films well mimicked that of the biogenic target, particularly with regard to $\mathrm{Ca} / \mathrm{P}$ ratio and the amount of $\mathrm{Mg}$ and $\mathrm{Na}$ ions. Remarkably, treatment of the as-deposited highly amorphous films at $400{ }^{\circ} \mathrm{C}$ for $1 \mathrm{~h}$ promoted an increase in crystallinity [73,74] (Figure 6). Indeed, XRD patterns of as-deposited films showed nanocrystalline domains (HA, Figure 6a), or an essentially amorphous phase (BAL, Figure 6b) consistent with the different crystalline degree of the targets. After annealing, films crystallized in a phase close to the natural apatite structure [75].

Demonstrations of high adhesion of the BAL films onto the surfaces of 3D objects, such as dental screws, have been also reported [74]. 
a)

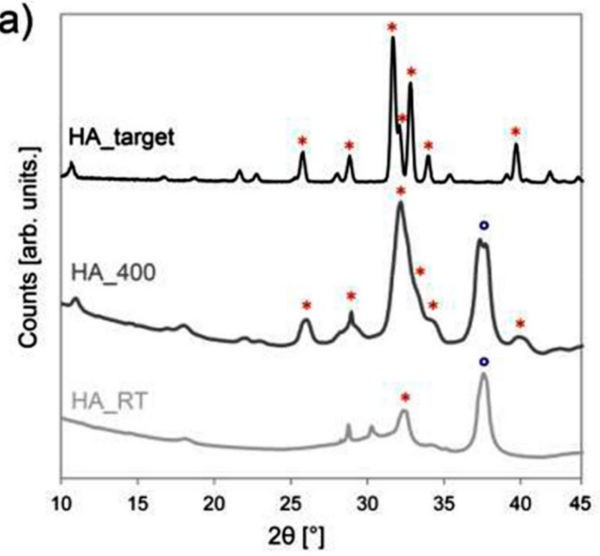

b)

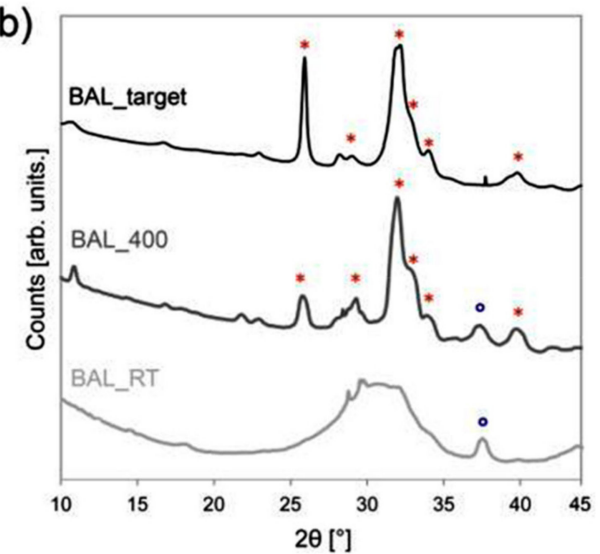

Figure 6. XRD spectra of the hydroxyapatite (HA) (a) and bone apatite-like (BAL) (b) targets; as-deposited and annealed films. Reprinted with permission from [73]. (C) 2017 Elsevier.

In light of these results, the adhesion, proliferation, and osteogenic differentiation of human dental pulp stem cells (hDPCs) on BAL thin films were evaluated and compared with those achieved on stoichiometric HA thin films, either as-deposited or after the thermal treatment [76]. Results well demonstrated that hDPSCs cultured on annealed BAL thin films preserved their morphology and homogeneously proliferated through the whole surface when compared with the other films, as shown in Figure 7a,c,e,g [76]. Furthermore, cells grown in an osteogenic medium on annealed BAL thin films were able to express osteogenic markers, reaching a higher commitment towards osteogenic differentiation with respect to as-deposited and annealed HA and as-deposited BAL films [76].
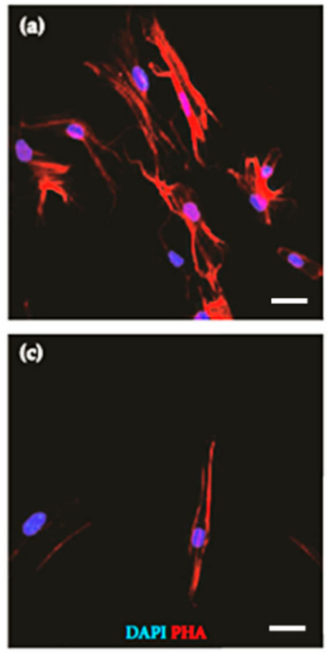
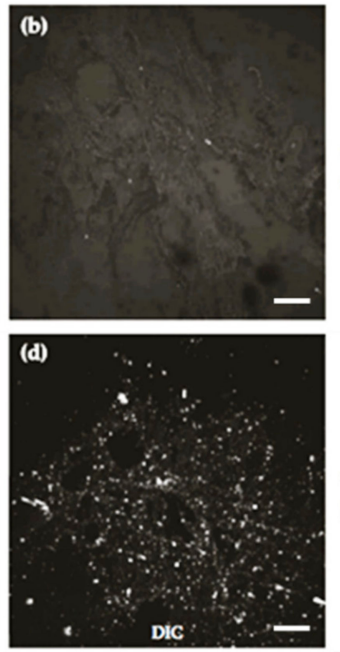
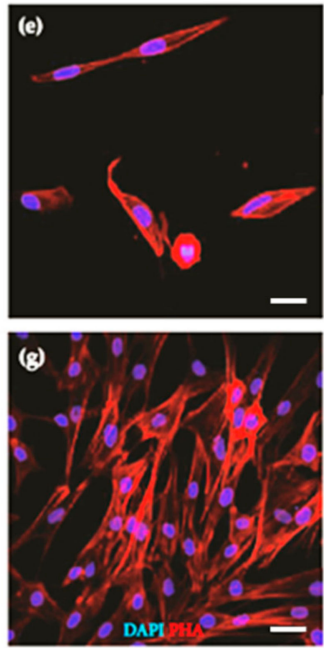
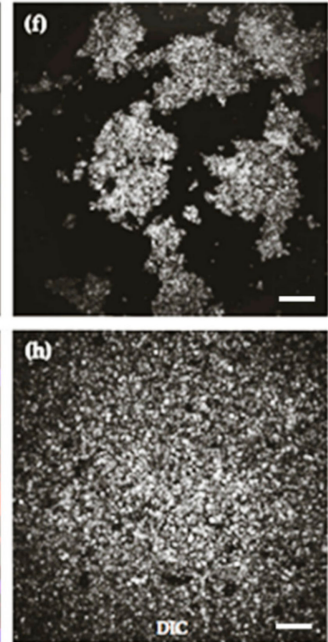

Figure 7. Immunofluorescence images (a,c,e,g) showing cell morphology of hDPSCs cultured on HA and BAL films and differential interface contrast microscopy images $(\mathbf{b}, \mathbf{d}, \mathbf{f}, \mathbf{h})$ representing film adhesion to the underlying surface at 7 days of culturing. Immunofluorescence analysis was performed against phalloidin (PHA). Nuclei were counterstained with 4',6-diamidino-2-phenylindole (DAPI). Scale bar is $10 \mu \mathrm{m}[76]$.

In the framework of biogenic coatings, PED has been used also for the fabrication of thin films made of bioglass [77]. Thin films of $45 \mathrm{~S} 5$ and $\mathrm{CaO}-$ rich (named $\mathrm{CaK}$ ) bioglasses were deposited by IJD on titanium alloy substrates [78]. The effect of the thermal annealing performed for $1 \mathrm{~h}$ at $600{ }^{\circ} \mathrm{C}$ and $750{ }^{\circ} \mathrm{C}$ for $45 \mathrm{~S} 5$ and $\mathrm{CaK}$, respectively, was also investigated [78]. The surface morphology of the as-deposited and annealed coatings was characterized by the presence of spherical aggregates, while the chemical composition of the films was very close to that of the bioactive glass target (Figure 8) [78]. 


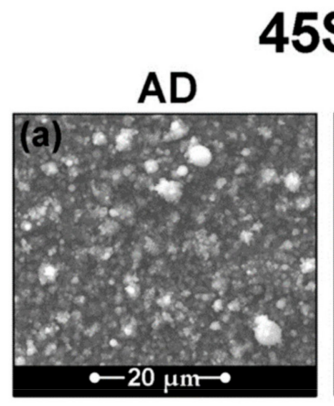

$45 S 5$
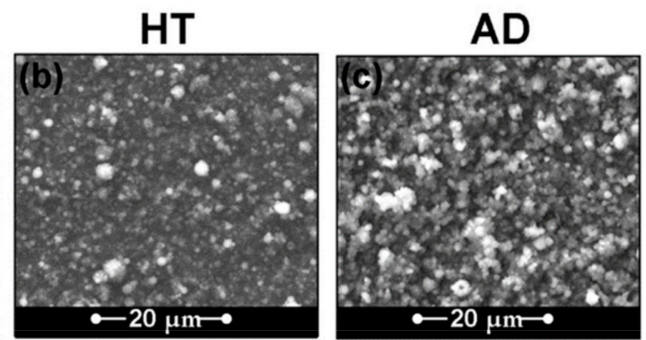

CaK
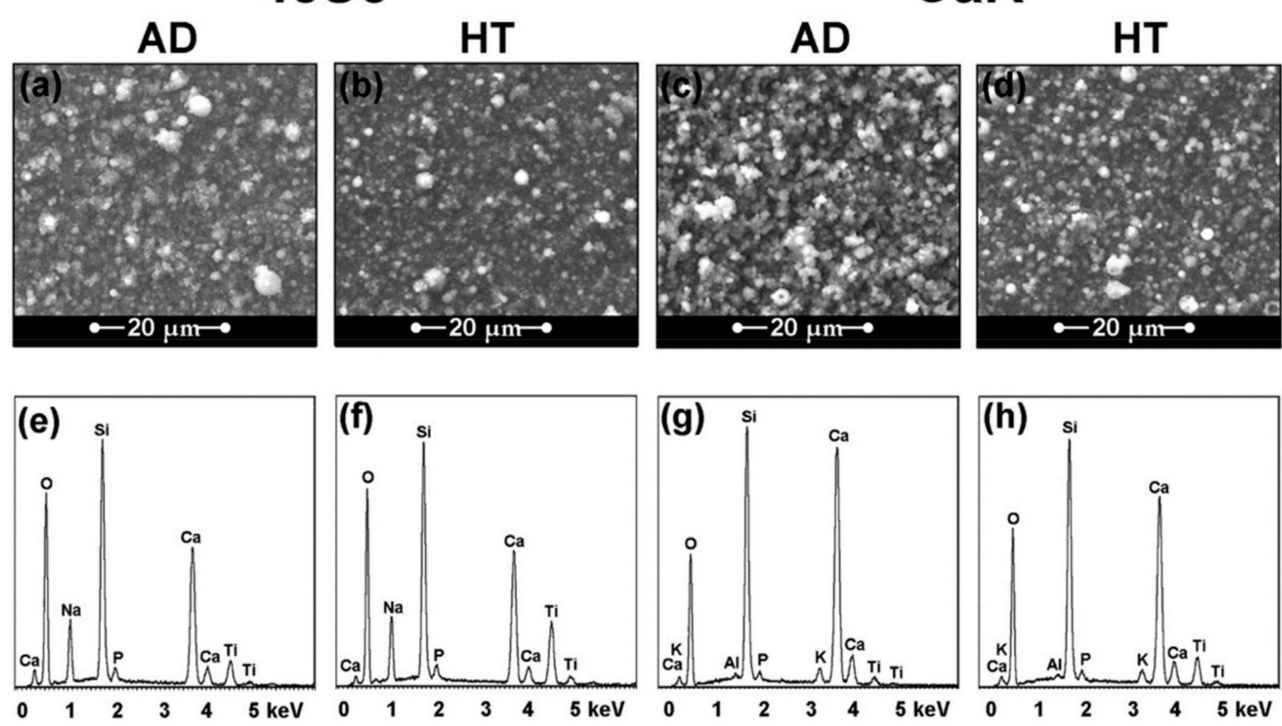

Figure 8. SEM images of as-deposited $(\mathbf{a}, \mathbf{c})$ and thermal annealed $(\mathbf{b}, \mathbf{d})$ coatings; results of EDX analysis on as-deposited $(\mathbf{e}, \mathbf{g})$ and thermal annealed $(\mathbf{f}, \mathbf{h})$ coatings. Reprinted with permission from [78]. (C) 2017 Elsevier.

Notably, the resistances to delamination of the bioglass films were found to closely correlate to their crystallinity. The $45 \mathrm{~S} 5$ annealed coatings were poorly crystalline, and consequently, exhibited poor resistance, as can be observed by evaluating the critical loads of partial and complete delamination and the worn track from the micro-scratch test (Figure 9). On the contrary, CaK annealed coatings were more crystalline and showed higher resistance to delamination [78].
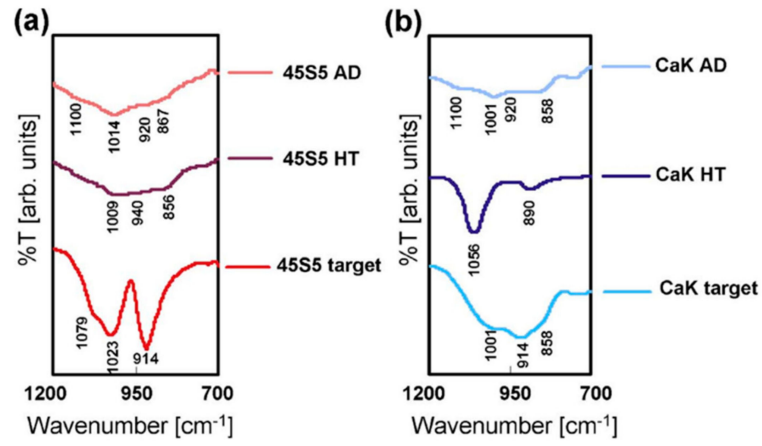

(c)

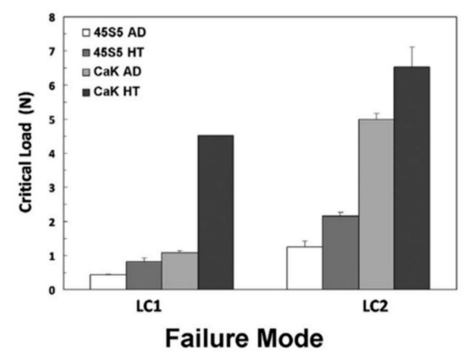

(d)

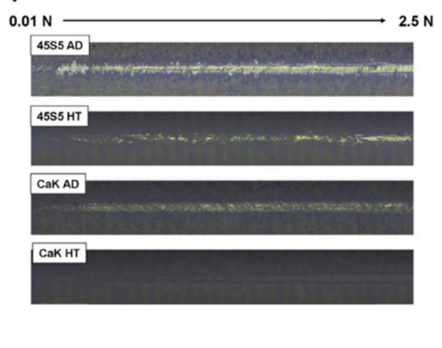

Figure 9. Fourier-transform infrared spectroscopy (FT-IR) spectra of $45 \mathrm{~S} 5$ (a) and CaK (b) targets and for as-deposited and heat-treated coatings. Critical loads for partial (LC1) and complete (LC2) delamination (c) and optical images (objective magnitude: $5 \times$ ) of the worn track (d) obtained by the micro-scratch test. 


\section{Antibacterial Thin Films by PED}

About four million healthcare-related infections occur per year in Europe, causing about 37,000 deaths, 16 million additional days of hospitalization, and a direct cost of seven billion Euros [79]. Infections can start from microbial adhesion on the implant surface immediately upon insertion, during surgery, because of hematogenous spreading of the microorganisms to the implant, or because of spreading from an adjacent infection site, leading, in any case, to the formation of a biofilm. Upon formation of the biofilm, microorganisms are well protected from the host immune system and from antibiotics, so they become capable of proliferating and invading other implants or adjacent bone sites [80]. If biofilm formation occurs, eradication of the infection requires implant removal and revision surgery, and, in some cases, can have dramatic consequences for the patient. Currently, the most successful strategy for preventing infections is systemic antibiotic therapy, which, however, increases the risk of systemic toxicity and of the development of resistant bacterial strains [81]. For this reason, inorganic antimicrobial coatings able to locally deliver antibacterial agents directly in the site of insertion without causing bacterial resistance, are extremely appealing [82,83]. In addition, antimicrobial coatings must not only be effective and biocompatible, but must also not impair osseointegration; i.e., the direct structural and functional contact between the implant and the host bone [84].

A possible strategy is to coat implantable materials with materials eliciting both bioactive and antibacterial effects through the incorporation of inorganic factors such metal nanoparticles in bioactive coatings [85-87]. Silver (Ag) is undoubtedly the workhorse among the many inorganic antibacterial species, thanks to its widely documented wide spectrum anti-microbial and anti-viral efficacy [88,89]. Recently, efforts have been focused to the fabrication of nanostructured Ag thin films to exploit the enhanced antibacterial properties of nanostructured materials compared to micro-structured materials [90-92].

The suitability of IJD technology for the fabrication of Ag nanostructured thin films onto titanium alloy and silicon oxide substrates was explored [93]. By ablating a pure metallic Ag target, IJD provided pure metallic Ag films which were nanostructured and highly homogeneous (Figure 10). Notably, differently from ceramics, the high thermal conductivity and density of the Ag target (about three times higher than that of BAL and YSZ) allow one to deposit very smooth films, with nanometric corrugation (mean surface roughness in the range 0.7-1.2 nm), with low amounts of particulate and a mean size of the grains of few nanometers [93]. Further, AFM highlighted that no significant variation of the grain size could be observed by increasing the film thickness (Figure 10).

For biomedical applications in which the control over the morphology is fundamental for the regulation of the balance between cytotoxicity and antimicrobial properties, the controlled dewetting of Ag thin films allowed some to obtain non-cytotoxic structures presenting antimicrobial properties [94,95]. The dewetting of thin films is a thermally-driven process, which, performed at a temperature below the melting point, leads to the evolvement of the surface morphology up to the formation of separate droplets/3D islands [96-98]. The dewetting process was carried out in air for $1 \mathrm{~h}$ with temperature varying from 200 to $600{ }^{\circ} \mathrm{C}$ on $\mathrm{Ag}$ thin films deposited by means of IJD technology onto silica substrate [99]. The morphological analysis highlighted that for dewetting process performed at $200^{\circ} \mathrm{C}$, the surface of the film was still continuous and only a few hillocks were found. Further, temperature increased up to $300{ }^{\circ} \mathrm{C}$ promoted the formation of micrometric holes and the partial exposure of the silica substrate; by further heating the film up to $600{ }^{\circ} \mathrm{C}$ the formation and separation of 3D islands was detected [99].

Among inorganic antibacterial materials, magnetite nanoparticles were demonstrated to impair biofilm growth by rapidly penetrating the biofilm pores in the presence of an external magnetic field [100]. HA/magnetite coatings have been fabricated by PPD. The composition well resembled the one of the target, although a random and inhomogeneous distribution of the magnetic particles on the film's surface was highlighted by both electrostatic force microscopy and scanning tunneling microscopy [101]. The antibacterial tests, performed by evaluating the adhesion of Escherichia coli after $4 \mathrm{~h}$ of incubation on HA/magnetite and HA coatings with and without the presence of an external magnetic field (intensity $1.45 \mathrm{~T}$ ), demonstrated the suitability of the HA/magnetite coatings in 
hindering the bacterial adhesion in comparison to HA coatings, independently from the application of the magnetic field [101]. According to the previous results [100], the presence of the magnetic field, induced by a permanent magnet placed below the samples, enhanced the anti-adhesive properties of the HA/magnetite coatings [101].

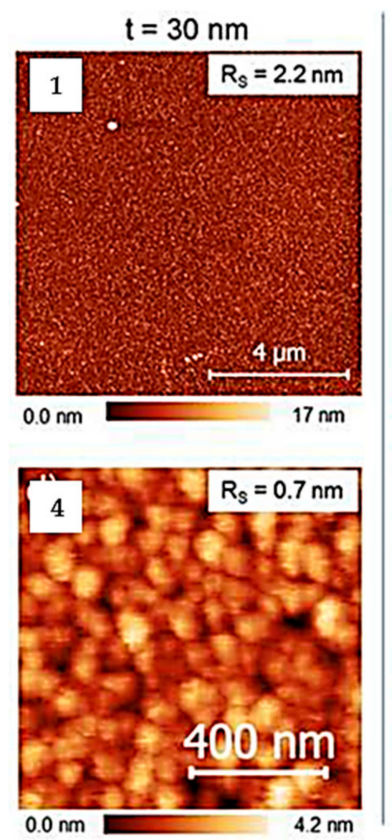

(a)

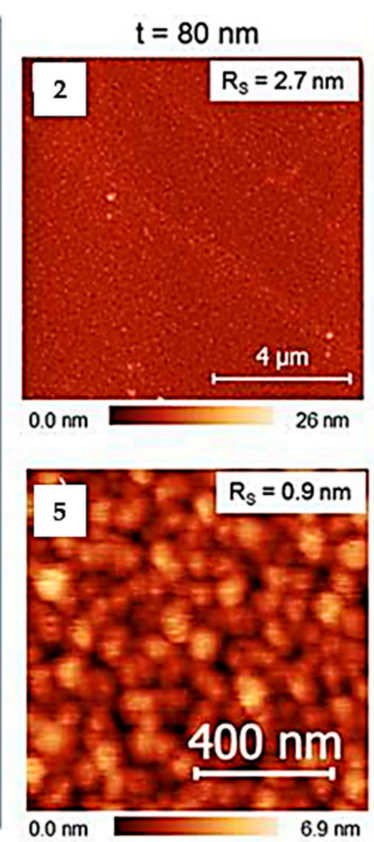

(b)

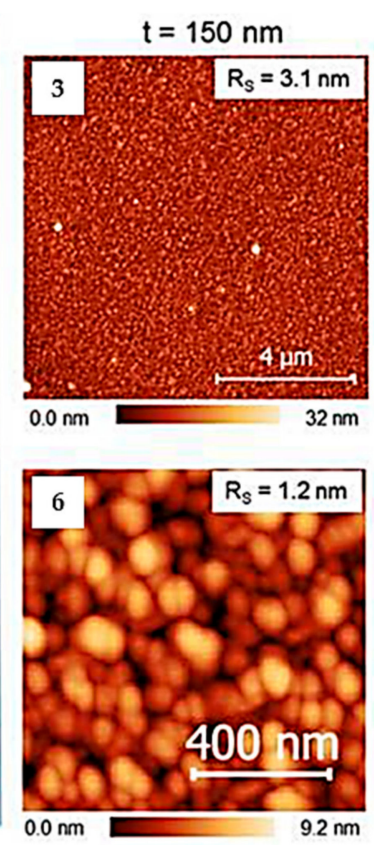

(c)

Figure 10. AFM images $(10 \mu \mathrm{m} \times 10 \mu \mathrm{m})$ of Ag coatings deposited on Si at three different thickness values: (a) $\mathrm{t}=48 \pm 8$, (b) $78 \pm 12$, and (c) $159 \pm 19 \mathrm{~nm}$. RMS roughness $\left(R_{\mathrm{s}}\right)$ values are indicated in the label for each image. Reprinted with permission from [93]. (C) 2019 Elsevier.

\section{Summary and Future Perspectives}

Despite the fact that PED has been used for several decades, application of PED to depositing coatings and thin films of biomedical interest is relatively new. However, in less than a decade, a significant number of manuscripts concerning the use of PED in the biomedical field have been published (Table 1), likely due to the entry in the market of more and more robust versions of the technology, such as IJD.

Table 1. Summary of the available literature on PED technology for biomedical applications.

\begin{tabular}{|c|c|c|c|}
\hline \multicolumn{4}{|c|}{ Hard Coatings for Articulating Surfaces } \\
\hline Target & Substrate & Coating's Main Features & References \\
\hline $\begin{array}{c}\mathrm{ZrO}_{2} \text { stabilized with } \\
\qquad \mathrm{Y}_{2} \mathrm{O}_{3}\end{array}$ & UHMWPE & $\begin{array}{l}\text { Fully cubic crystalline phase; } \\
\text { excellent adhesion to the plastic } \\
\text { substrate; high strength to normal } \\
\text { plastic deformation. }\end{array}$ & {$[31,39,40]$} \\
\hline $\begin{array}{l}\mathrm{ZrO}_{2} \text { stabilized with } \\
\qquad \mathrm{Y}_{2} \mathrm{O}_{3}\end{array}$ & AISI 316-L & $\begin{array}{l}\text { Low roughness and high } \\
\text { thickness; reduction of the wear } \\
\text { rate of polymeric counterpart; } \\
\text { steady friction coefficient during } \\
\text { the tribological test. }\end{array}$ & [42] \\
\hline
\end{tabular}


Table 1. Cont.

\begin{tabular}{|c|c|c|c|}
\hline \multicolumn{4}{|c|}{ Hard Coatings for Articulating Surfaces } \\
\hline Target & Substrate & Coating's Main Features & References \\
\hline $\begin{array}{l}\mathrm{ZrO}_{2} \text { stabilized with } \\
\qquad \mathrm{Y}_{2} \mathrm{O}_{3}\end{array}$ & $\begin{array}{c}\text { Titanium and titanium } \\
\text { alloys }\end{array}$ & $\begin{array}{l}\text { Significant reduction of UHMWPE } \\
\text { wear rate; prevention of the } \\
\text { formation of abrasion scratches on } \\
\text { the substrate; no cytotoxic effects. }\end{array}$ & [43-45] \\
\hline $\begin{array}{l}\mathrm{ZrO}_{2} \text { stabilized with } \\
\qquad \mathrm{Y}_{2} \mathrm{O}_{3}\end{array}$ & $\begin{array}{l}\text { Glass, silicon, } \\
\text { titanium, PEEK }\end{array}$ & $\begin{array}{l}\text { Morphology independent from } \\
\text { the substrate in case of flat } \\
\text { substrates; morphology } \\
\text { resembling the one of the substrate } \\
\text { in case of rough substrates. }\end{array}$ & [48] \\
\hline $75 \% \mathrm{Al}_{2} \mathrm{O}_{3} / 25 \% \mathrm{ZrO}_{2}$ & AISI 420 & $\begin{array}{l}\text { High adhesion to the substrate; } \\
\text { increase of the surface roughness } \\
\text { along with the thickness. }\end{array}$ & {$[51,52]$} \\
\hline \multicolumn{4}{|c|}{ Bioactive Coatings and Thin Films } \\
\hline Target & Substrate & Coating's Main Features & References \\
\hline Sintered HA & Titanium alloy & $\begin{array}{l}\text { Transition from amorphous to } \\
\text { crystalline coatings by means of } \\
\text { the thermal treatment of the } \\
\text { deposited coating; cell adhesion } \\
\text { and proliferation on both } \\
\text { as-deposited and annealed } \\
\text { coatings. }\end{array}$ & [58] \\
\hline $\begin{array}{l}\text { CaP target doped with } \\
\mathrm{Sr}^{2+}\end{array}$ & PEEK & $\begin{array}{l}\text { Same stoichiometry of the target; } \\
\text { dense and uniform packing of } \\
\text { spherical-like grains; } \mathrm{Sr}^{2+} \text { in the } \\
\text { coating increased the surface } \\
\text { roughness and decreased the } \\
\text { water contact angle. }\end{array}$ & [65] \\
\hline $\begin{array}{c}\text { Biogenic HA } \\
\text { (deproteinized bovine } \\
\text { bone shaft) }\end{array}$ & Titanium & $\begin{array}{l}\text { Composition well mimicking that } \\
\text { of the target; increase in } \\
\text { crystallinity up to that typical of } \\
\text { biogenic apatite through the } \\
\text { thermal treatment of the as } \\
\text { deposited films; high adhesion on } \\
\text { the surface of 3D objects. }\end{array}$ & {$[73,74]$} \\
\hline $\begin{array}{c}\text { Biogenic HA } \\
\text { (deproteinized bovine } \\
\text { bone shaft) }\end{array}$ & Glass & $\begin{array}{l}\text { hDPSCs cultured on annealed } \\
\text { films preserved their morphology } \\
\text { and homogeneously proliferated } \\
\text { through the whole surface; cells } \\
\text { grown in an osteogenic medium } \\
\text { on annealed thin films expressed } \\
\text { osteogenic markers. }\end{array}$ & [76] \\
\hline $\begin{array}{l}45 \mathrm{~S} 5 \text { and } \mathrm{CaK} \\
\text { bioglasses }\end{array}$ & Titanium alloy & $\begin{array}{l}\text { Spherical aggregates on both } \\
\text { as-deposited and annealed } \\
\text { coatings; chemical composition } \\
\text { analogous to that of the starting } \\
\text { bioactive glasses; resistance to } \\
\text { delamination closely correlated to } \\
\text { the crystallinity: the higher the } \\
\text { crystallinity of the coating the } \\
\text { higher the resistance. }\end{array}$ & [78] \\
\hline
\end{tabular}


Table 1. Cont.

\begin{tabular}{|c|c|c|c|}
\hline \multicolumn{4}{|c|}{ Antibacterial Thin Films } \\
\hline Target & Substrate & Coating's Main Features & References \\
\hline $\mathrm{Ag}$ & $\begin{array}{l}\text { Titanium alloy and } \\
\text { silicon dioxide }\end{array}$ & $\begin{array}{l}\text { Composition resembling the one } \\
\text { of the target; homogeneity in } \\
\text { thickness; presence of grains } \\
\text { composed by small subunits with } \\
\text { a size of few nm; no variation of } \\
\text { the grains' diameter with the } \\
\text { increase of the film thickness. }\end{array}$ & [93] \\
\hline $\mathrm{Ag}$ & Silicon dioxide & $\begin{array}{l}\text { Formation and separation of } 3 \mathrm{D} \\
\text { islands from the coating when } \\
\text { subjected to a dewetting process } \\
\text { carried out at } 600{ }^{\circ} \mathrm{C} \text { for } 1 \mathrm{~h} .\end{array}$ & [99] \\
\hline $\mathrm{HA} /$ magnetite & Silicon wafers & $\begin{array}{l}\text { Composition resembling the one } \\
\text { of the target, despite the random } \\
\text { and inhomogeneous distribution } \\
\text { of the magnetic particles on the } \\
\text { surface; the coatings hindered the } \\
\text { E. coli adhesion. }\end{array}$ & [101] \\
\hline
\end{tabular}

The deposition of functional metallic coatings represents one of the most promising research fields in which PED technology can provide highly performing solutions. For instance, due to its suitability to process thermosensitive substrates, PED can be used to deposit antibacterial coatings onto electrospun polymeric substrates with the aim to produce patches for wound healing and tissue regeneration (unpublished results by the authors). Furthermore, PED technology can be exploited to coat polymeric fibers with conductive materials for wearable electronics [102] and electrically conductive textiles [103], where flexible and well-adhesive conductive coatings are desired.

Besides, the deposition of bioactive or fully biomimetic coatings and the promising results obtained from the in vitro tests in terms of bioactivity, mechanical properties, and adhesion, certainly represent a valuable starting point for further in vivo investigations, aside from a novel promising strategy for endowing bio-inert implantable scaffolds with novel functional properties $[104,105]$.

From that perspective, we envision that biofunctional coatings might be relevant, especially in those medical applications where the implant is used for the treatment or therapy of a chronic pathology. Envisioned fields of interest also include neurodegenerative diseases and prosthetics for the central and peripheral nervous system. In particular, high-surface area metallic electrodes for neural recording and stimulation [106] may be realized by PED, even on highly flexible elastomeric substrates, and conductive and dielectric thin films for batteries, pacemakers, and devices based on organic bioelectronics interfacing with the human body [107].

Nevertheless, some crucial aspects concerning the quality of the coatings fabricated by PED still deserve deeper investigation. For instance, whereas crystalline coatings can be easily deposited by PED from target materials exhibiting simple chemical composition (i.e., $\mathrm{ZrO}_{2}$ ) [15], this results in more challenges when complex or multiphase materials (i.e., calcium phosphates) are involved [58,73]. In these cases, the achievement of correct crystallinity (close to that of natural bone apatite), and therefore, also of optimal mechanical properties (coating toughness, hardness, and adhesion) still requires a post deposition thermal treatment. Obviously, this aspect is particularly relevant when the deposition is carried out at room temperature to allow the coating of soft and heat-sensitive materials [65].

In addition, some technological issues have still to be solved; for instance, the necessity of periodic cleaning of the auxiliary electrode in the IJD configuration or the relative costs for the installation of the equipment, albeit this feature is shared by all the main PVD techniques working in high vacuum. Finally, it should be remarked that PED is a line-of-sight technique, so the coating of complex shapes 
or 3D substrates is not trivial; in these cases, multi-step depositions or multi-axis rotating substrate holders must be considered to obtain homogeneous coatings.

\section{Conclusions}

In this work, we reviewed the recent technological developments and applications of PED in the biomedical field in light of its high versatility, mainly due to:

- The possibility to vary the depositions of a wide range of materials in a broad spectrum of operating independent conditions;

- The possibility to efficiently operate at low temperatures thanks to the high plasma density;

- The high fidelity in stoichiometry transfer from the target to the coating;

- The technological maturity and the competitive upscaling costs compared to similar techniques, such as PLD.

PED technology promises to conquer a remarkable role in the field of coating technology, even in the biomedical field where it can still be considered at its infancy.

Author Contributions: Conceptualization, M.B.; methodology, A.L., M.B. and C.G.; writing-original draft preparation, A.L. and M.B.; writing - review and editing, F.B., C.G. and M.L.F.; supervision, M.B. and C.G. All authors have read and agreed to the published version of the manuscript.

Funding: This research received no external funding.

Acknowledgments: The authors dedicate this work to the memory of Carlo Taliani, that pioneered PED for spintronics and coatings.

Conflicts of Interest: The authors declare no conflict of interest.

\section{References}

1. Wan, R.; Yang, M.; Zhou, Q.; Zhang, Q. Transparent conductive indium zinc oxide films prepared by pulsed plasma deposition. J. Vac. Sci. Technol. A 2012, 30, 61508. [CrossRef]

2. Arisi, E.; Bergenti, I.; Cavallini, M.; Murgia, M.; Riminucci, A.; Ruani, G.; Dediu, V. Room temperature deposition of magnetite thin films on organic substrate. J. Magn. Magn. Mater. 2007, 316, 410-412. [CrossRef]

3. Huang, Y.; Zhang, Q.; Li, G. Transparent conductive tungsten-doped tin oxide polycrystalline films prepared on quartz substrates. Semicond. Sci. Technol. 2009, 24, 15003. [CrossRef]

4. Huang, Y.W.; Li, G.F.; Feng, J.H.; Zhang, Q. Investigation on structural, electrical and optical properties of tungsten doped tin oxide thin films. Thin Solid Films 2010, 518, 1892-1896. [CrossRef]

5. Yao, Q.J.; Li, S.X.; Zhang, Q. Influences of channel metallic composition on indium zinc oxide thin-film transistor performance. Semicond. Sci. Technol. 2011, 26, 85011. [CrossRef]

6. Huang, Y.W.; Zhang, Q.; Xi, J.H.; Ji, Z.G. Transparent conductive p-type lithium-doped nickel oxide thin films deposited by pulsed plasma deposition. Appl. Surf. Sci. 2012, 258, 7435-7439. [CrossRef]

7. Yang, M.; Pu, H.F.; Zhou, Q.F.; Zhang, Q. Transparent p-type conducting K-doped NiO films deposited by pulsed plasma deposition. Thin Solid Films 2012, 520, 5884-5888. [CrossRef]

8. Witke, T.; Lenk, A.; Siemroth, P. Channel spark discharges for thin film technology. In Proceedings of the 17th International Symposium on Discharges and Electrical Insulation in Vacuum, Berkeley, CA, USA, 21-26 July 1996.

9. Witke, T.; Ziegele, H. Plasma state in pulsed arc, laser and electron deposition. Surf. Coat. Technol. 1997, 97, 414-419. [CrossRef]

10. Dediu, V.I.; Jiang, J.D.; Matacotta, F.C.; Scardi, P.; Lazzarino, M.; Nieva, G.; Civale, L. Deposition of $\mathrm{MBa}_{2} \mathrm{Cu}_{3} \mathrm{O}_{7-x}$ thin films by channel-spark method. Supercond. Sci. Technol. 1995, 8, 160-164. [CrossRef]

11. Henda, R.; Wilson, G.; Gray-Munro, J.; Alshekhli, O.; McDonald, A.M. Preparation of polytetrafluoroethylene by pulsed electron ablation: Deposition and wettability aspects. Thin Solid Films 2012, 520, 1885-1889. [CrossRef]

12. Taliani, C.; Nozar, P. Method for Depositing Metal Oxide Films. U.S. Patent No. 12/809,326, 3 March 2011.

13. Lotti, R.; Nozar, P.; Taliani, C. Device for Generating Plasma and for Directing a Flow of Electrons towards a Target. U.S. Patent No. 8803425B2, 12 August 2014. 
14. Bianchi, M.; Russo, A.; Taliani, C.; Marcacci, M. Pulsed Plasma Deposition (PPD) Technique, in Dekker Encyclopedia of Nanoscience and Nanotechnology, 3rd ed.; Taylor and Francis: New York, NY, USA, 2015; pp. 1-7.

15. Bianchi, M.; Russo, A.; Lopomo, N.; Boi, M.; Maltarello, M.C.; Sprio, S.; Baracchi, M.; Marcacci, M. Pulsed plasma deposition of zirconia thin films on UHMWPE: Proof of concept of a novel approach for joint prosthetic implants. J. Mater. Chem. B 2013, 1, 310-318. [CrossRef]

16. Harshavardhan, K.S.; Strikovski, M. Second-Generation HTS Conductors; Goyal, A., Ed.; Springer: New York, NY, USA, 2005; pp. 109-133.

17. Henda, R.; Al-Shareeda, O.; McDonald, A.; Pratt, A. Deposition of iron pyrite via pulsed electron ablation. Appl. Phys. A 2012, 108, 967-974. [CrossRef]

18. Strikovski, M.; Harshavardhan, K.S. Parameters that control pulsed electron beam ablation of materials and film deposition processes. Appl. Phys. Lett. 2003, 82, 853-855. [CrossRef]

19. Chandra, V.; Manoharan, S.S. Pulsed electron beam deposition of highly oriented thin films of polytetrafluoroethylene. Appl. Surf. Sci. 2008, 254, 4063-4066. [CrossRef]

20. Mathis, J.E.; Christen, H.M. Factors that influence particle formation during pulsed electron deposition of YBCO precursors. Physica C 2007, 459, 47-51. [CrossRef]

21. Christen, H.M.; Lee, D.F.; List, F.A.; Cook, S.W.; Leonard, K.J.; Heatherly, L.; Martin, P.M.; Paranthaman, P.; Goyal, A.; Rouleau, C.M. Pulsed electron deposition of fluorine-based precursors for $\mathrm{YBa}_{2} \mathrm{Cu}_{3} \mathrm{O}_{7-x}$-coated conductors. Supercond. Sci. Technol. 2005, 18, 1168-1175. [CrossRef]

22. Skocdopolova, L. Device for Generating Plasma and Directing an Electron Beam towards a Target. WO Patent 2013/186697, 25 December 2013.

23. Mazzer, M.; Rampino, S.; Gombia, E.; Bronzoni, M.; Bissoli, F.; Pattini, F.; Calicchio, M.; Kingma, A.; Annoni, F.; Calestani, D.; et al. Progress on low-temperature pulsed electron deposition of CuInGaSe 2 solar cells. Energies 2016, 9, 207-218. [CrossRef]

24. Menossi, D.; Di Mare, S.; Rimmaudo, I.; Artegiani, E.; Tedeschi, G.; Pena, J.L.; Piccinell, F.; Salavei, F.; Romeo, A. SnS by Ionized Jet Deposition for photovoltaic applications. In Proceedings of the IEEE 44th Photovoltaic Specialist Conference (PVSC), Washington, DC, USA, 25-30 June 2017.

25. Skocdopole, J.; Aversa, L.; Golan, M.; Schenk, A.; Baldi, G.; Kratochvilova, I.; Kalvoda, L.; Nozar, P. Preparing of the chameleon coating by the ion jet deposition method. Acta Polytech. CTU Proc. 2017, 9, 19-25. [CrossRef]

26. Skocdopole, J.; Kalvoda, L.; Nozar, P.; Netopilik, M. Preparation of polymeric coatings by ionized jet deposition method. Chem. Pap. 2018, 72, 1735-1739. [CrossRef]

27. Zenker, R. Electron Beam Surface Technologies; Wang, Q.J., Chung, Y.W., Eds.; Springer: Boston, MA, USA, 2013.

28. Duta, L.; Popescu, A.C. Current status on pulsed laser deposition of coatings from animal-origin calcium phosphate sources. Coatings 2019, 9, 335-376. [CrossRef]

29. Shia, J.Z.; Chena, C.Z.; Yub, H.J.; Zhang, S.J. The effect of process conditions on the properties of bioactive films prepared by magnetron sputtering. Vacuum 2008, 83, 249-256. [CrossRef]

30. Pelletier, J.; Anders, A. Plasma-based ion implantation and deposition: A review of physics, technology, and applications. IEEE Trans. Plasma Sci. 2005, 33, 1944-1959. [CrossRef]

31. Peng, C.; Zhao, Y.; Jin, S.; Wang, J.R.; Liu, R.; Liu, H.; Shi, W.; Kolawole, K.S.; Ren, L.; Yu, B.; et al. Antibacterial $\mathrm{TiCu} / \mathrm{TiCuN}$ multilayer films with good corrosion resistance deposited by axial magnetic field-enhanced arc ion plating. ACS Appl. Mater. Interfaces 2019, 11, 125-136. [CrossRef] [PubMed]

32. Döring, J.; Crackau, M.; Nestler, C.; Welzel, F.; Bertrand, J.; Lohmann, C.H. Characteristics of different cathodic arc deposition coatings on CoCrMo for biomedical applications. J. Mech. Behav. Biomed. Mater. 2019, 97, 212-221. [CrossRef] [PubMed]

33. Sobieraj, M.C.; Rimnac, C.M. Ultra high molecular weight polyethylene: Mechanics, morphology, and clinical behavior. J. Mech. Behav. Biomed. Mater. 2009, 2, 433-443. [CrossRef] [PubMed]

34. Dumbleton, J.H.; Manley, M.T.; Edidin, A.A. A literature review of the association between wear rate and osteolysis in total hip arthroplasty. J. Arthroplast. 2002, 17, 649-661. [CrossRef]

35. Ingham, E.; Fisher, J. The role of macrophages in osteolysis of total joint replacement. Biomaterials 2005, 26, 1271-1286. [CrossRef]

36. Drees, P.; Eckardt, A.; Gay, R.E.; Gay, S.; Huber, L.C. Mechanisms of disease: Molecular insights into aseptic loosening of orthopedic implants. Nat. Clin. Pract. Rheumatol. 2007, 3, 165-171. [CrossRef] 
37. Kaufman, A.M.; Alabre, C.I.; Rubash, H.E.; Shanbhag, A.S. Human macrophage response to UHMWPE, TiAlV, CoCr, and alumina particles: analysis of multiple cytokines using protein arrays. J. Biomed. Mater. Res. Part A 2008, 84, 464-474. [CrossRef]

38. Labek, G.; Thaler, M.; Janda, W.; Agreiter, M.; Stöckl, B. Revision rates after total joint replacement: Cumulative, Cumulative results from worldwide joint register datasets. J. Bone Joint Surg. Br. 2011, 93, 293-297. [CrossRef]

39. Russo, A.; Bianchi, M.; Lopomo, N.; Boi, M.; Ortolani, A.; Marchiori, G.; Gambardella, A.; Maltarello, M.C.; Visani, A.; Marcacci, M. Hard ceramic thin films on UHMWPE insert: A novel approach for longlasting joint implants. Orthop. Proc. 2016, 98, 10.

40. Bianchi, M.; Boi, M.; Lopomo, N. Nanomechanical characterization of zirconia thin films deposited on UHMWPE by pulsed plasma deposition. J. Mech. Med. Biol. 2015, 15, 1550070-1550085. [CrossRef]

41. Marchiori, G.; Lopomo, N.; Boi, M.; Berni, M.; Bianchi, M.; Gambardella, A.; Visani, A.; Russo, A.; Marcacci, M. Optimizing thickness of ceramic coatings on plastic components for orthopedic applications: A finite element analysis. Mater. Sci. Eng. C 2016, 58, 381-388. [CrossRef] [PubMed]

42. Berni, M.; Marchiori, G.; Gambardella, A.; Boi, M.; Bianchi, M.; Russo, A.; Visani, A.; Marcacci, M.; Pavanc, P.G.; Lopomo, N.F. Effects of working gas pressure on zirconium dioxide thin film prepared by pulsed plasma deposition: Roughness, wettability, friction and wear characteristics. J. Mech. Behav. Biomed. Mater 2017, 72, 200-208. [CrossRef] [PubMed]

43. Berni, M.; Lopomo, N.; Marchiori, G.; Gambardella, A.; Boi, M.; Bianchi, M.; Visani, A.; Pavan, P.; Russo, A.; Marcacci, M. Tribological characterization of zirconia coatings deposited on Ti6Al4V components for orthopedic applications. Mater. Sci. Eng. 2016, 62, 643-655. [CrossRef] [PubMed]

44. Bianchi, M.; Lopomo, N.; Boi, M.; Gambardella, A.; Marchiori, G.; Berni, M.; Pavan, P.; Marcacci, M.; Russo, A. Ceramic thin films realized by means of pulsed plasma deposition technique: Applications for orthopedics. J. Mech. Med. Biol. 2015, 15, 1540002-1540009. [CrossRef]

45. Bianchi, M.; Gambardella, A.; Berni, M.; Panseri, S.; Montesi, M.; Lopomo, N.; Tampieri, A.; Marcacci, M.; Russo, A. Surface morphology, tribological properties and in vitro biocompatibility of nanostructured zirconia thin films. J. Mater. Sci. Mater. Med. 2016, 27, 95-105. [CrossRef]

46. Dong, H.; Shi, W.; Bell, T. Potential of improving tribological performance of UHMWPE by engineering the Ti6Al4V counterfaces. Wear 1999, 225, 146-153. [CrossRef]

47. Xiong, D.; Ge, S. Friction and wear properties of UHMWPE $/ \mathrm{Al}_{2} \mathrm{O}_{3}$ ceramic under different lubricating conditions. Wear 2001, 250, 242-245. [CrossRef]

48. Gambardella, A.; Berni, M.; Russo, A.; Bianchi, M. A comparative study of the growth dynamics of zirconia thin films deposited by ionized jet deposition onto different substrates. Surf. Coat. Technol. 2018, 337, 306-312. [CrossRef]

49. Kurtz, S.M.; Kocagoz, S.; Arnholt, C.; Huet, R.; Ueno, M.; Walter, W.L. Advances in zirconia toughened alumina biomaterials for total joint replacement. J. Mech. Behav. Biomed. Mater. 2014, 31, 107-116. [CrossRef] [PubMed]

50. De Aza, A.H.; Chevalier, J.; Fantozzi, G.; Schehl, M.; Torrecillas, R. Crack growth resistance of alumina, zirconia and zirconia toughened alumina ceramics for joint prostheses. Biomaterials 2002, 23, 937-945. [CrossRef]

51. Russo, A.; Lopomo, N.; Bianchi, M.; Boi, M.; Ortolani, A.; Gambardella, A.; Marchiori, G.; Maltarello, M.C.; Visani, A.; Marcacci, M. Protective zirconia-toughened-alumina films deposited on the UHMWPE insert by the pulsed plasma deposition method: Preliminary results. Orthop. Proc. 2018, 98, 10.

52. Kaciulis, S.; Mezzi, A.; Bianchi, M.; Gambardella, A.; Boi, M.; Liscio, F.; Marcacci, M.; Russo, A. Ceramic coatings for orthopaedic implants: Preparation and characterization. Surf. Interface Anal. 2015, 48, 616-620. [CrossRef]

53. Junker, R.; Dimakis, A.; Thoneick, M.; Jansen, J.A. Effects of implant surface coatings and composition on bone integration: A systematic review. Clin. Oral Implants Res. 2009, 20, 185-206. [CrossRef]

54. Liu, X.; Chu, P.K.; Ding, C. Surface modification of titanium, titanium alloys, and related materials for biomedical applications. Mater. Sci. Eng. R Rep. 2004, 57, 49-121. [CrossRef]

55. Nijhuis, A.W.; Leeuwenburgh, S.C.; Jansen, J.A. Wet-chemical deposition of functional coatings for bone implantology. Macromol. Biosci. 2010, 10, 1316-1329. [CrossRef] 
56. Surmenev, R.A. A review of plasma-assisted methods for calcium phosphate-based coatings fabrication. Surf. Coat. Technol. 2012, 206, 2035-2056. [CrossRef]

57. Surmenev, R.A.; Surmeneva, M.A.; Ivanova, A.A. Significance of calcium phosphate coatings for the enhancement of new bone osteogenesis-A review. Acta Biomater. 2014, 10, 557-579. [CrossRef]

58. Boi, M.; Bianchi, M.; Gambardella, A.; Liscio, F.; Kaciulis, S.; Visani, A.; Barbalinardo, M.; Valle, F.; Iafisco, M.; Lungaro, L.; et al. Tough and adhesive nanostructured calcium phosphate thin films deposited by the pulsed plasma deposition method. RSC Adv. 2015, 5, 78561-78571. [CrossRef]

59. Kurtz, S.M.; Devine, J.N. PEEK biomaterials in trauma, orthopedic, and spinal implants. Biomaterials 2007, 28, 4845-4869. [CrossRef] [PubMed]

60. Du, Y.W.; Zhang, L.N.; Hou, Z.T.; Ye, X.; Gu, H.S.; Yan, G.P.; Shang, P. Physical modification of polyetheretherketone for orthopedic implants. Front. Mater. Sci. 2014, 8, 313-324. [CrossRef]

61. Toth, J.M.; Wang, M.; Estes, B.T.; Scifert, J.L.; Seim Iii, H.B.; Turner, A.S. Polyetheretherketone as a biomaterial for spinal applications. Biomaterials 2006, 27, 324-334. [CrossRef] [PubMed]

62. Williams, D.F.; McNamara, A.; Turner, R.M. Potential of polyetheretherketone (PEEK) and carbon-fibre-reinforced PEEK in medical applications. J. Mater. Sci. Lett. 1987, 6, 188-190. [CrossRef]

63. Zhao, M.; An, M.; Wang, Q.; Liu, X.; Lai, W.; Zhao, X.; Wei, S.; Ji, J. Quantitative proteomic analysis of human osteoblast-likeMG-63 cells in response to bioinert implant material titanium and polyetheretherketone. J. Proteome 2012, 75, 3560-3573. [CrossRef]

64. Sagomonyants, K.B.; Jarman-Smith, M.L.; Devine, J.N.; Aronow, M.S.; Gronowicz, G.A. The in vitro response of human osteoblasts to polyetheretherketone (PEEK) substrates compared to commercially pure titanium. Biomaterials 2008, 29, 1563-1572. [CrossRef]

65. Bianchi, M.; Degli Esposti, L.; Ballardini, A.; Liscio, F.; Berni, M.; Gambardella, A.; Leeuwenburghd, S.G.C.; Sprio, S.; Tampieri, A.; Iafisco, M. Strontium doped calcium phosphate coatings on poly(etheretherketone) (PEEK) by pulsed electron deposition. Surf. Coat. Technol. 2017, 319, 191-199. [CrossRef]

66. Marie, P.J. Strontium as therapy for osteoporosis. Curr. Opin. Pharmacol. 2005, 5, 633-636. [CrossRef]

67. Braceras, I.; Vera, C.; Izquierdo, A.A.; Muñoz, R.; Lorenzo, J.; Alvareza, N.; Maeztu, M.A. Ion implantation induced nanotopography on titanium and bone cell adhesion. Appl. Surf. Sci. 2014, 310, 24-30. [CrossRef]

68. Deligianni, D.D.; Katsala, N.D.; Koutsoukos, P.G.; Missirlis, Y.F. Effect of surface roughness of hydroxyapatite on human bone marrow cell adhesion, proliferation, differentiation and detachment strength. Biomaterials 2000, 22, 87-96. [CrossRef]

69. Boanini, E.; Gazzano, M.; Bigi, A. Ionic substitutions in calcium phosphates synthesized at low temperature. Acta Biomater. 2010, 6, 1882-1894. [CrossRef] [PubMed]

70. Graziani, G.; Bianchi, M.; Sassoni, E.; Russo, A.; Marcacci, M. Ion-substituted calcium phosphate coatings deposited by plasma-assisted techniques: A review. Mater. Sci. Eng. C 2017, 74, 219-229. [CrossRef] [PubMed]

71. Graziani, G.; Boi, M.; Bianchi, M. A review on ionic substitutions in hydroxyapatite thin films: Towards complete biomimetism. Coatings 2018, 8, 269-285. [CrossRef]

72. Rau, J.V.; Cacciotti, I.; Laureti, S.; Fosca, M.; Varvaro, G.; Latini, A. Bioactive, nanostructured Si-substituted hydroxyapatite coatings on titanium prepared by pulsed laser deposition. J. Biomed. Mater. Res. B Appl. Biomater. 2015, 103, 1621-1631. [CrossRef] [PubMed]

73. Bianchi, M.; Gambardella, A.; Graziani, G.; Liscio, F.; Maltarello, M.C.; Boi, M.; Berni, M.; Bellucci, D.; Marchiori, G.; Valle, F.; et al. Plasma-assisted deposition of bone apatite-like thin films from natural apatite. Mater. Lett. 2017, 199, 32-36. [CrossRef]

74. Graziani, G.; Berni, M.; Gambardella, A.; De Carolis, M.; Cristina Maltarello, M.; Boi, M.; Carnevale, G.; Bianchi, M. Fabrication and characterization of biomimetic hydroxyapatite thin films for bone implants by direct ablation of a biogenic source. Mater. Sci. Eng. C 2019, 99, 853-862. [CrossRef]

75. Miller, L.M.; Vairavamurthy, V.; Chance, M.R.; Mendelsohn, R.; Paschalis, E.P.; Betts, F.; Boskey, A.L. In situ analysis of mineral content and crystallinity in bone using infrared micro-spectroscopy of the $v_{4} \mathrm{PO}_{4}{ }^{3-}$ vibration. Biochim. Biophys. Acta 2001, 1527, 11-19. [CrossRef]

76. Bianchi, M.; Pisciotta, A.; Bertoni, L.; Berni, M.; Gambardella, A.; Visani, A.; Russo, A.; de Pol, A.; Carnevale, G. Osteogenic differentiation of hDPSCs on biogenic bone apatite thin films. Stem Cells Int. 2017, 2017, 1-10.

77. Hench, L.L. The story of Bioglass ${ }^{\circledR}$. J. Mater. Sci. Mater. Med. 2006, 17, 967-978. [CrossRef] 
78. Bellucci, D.; Bianchi, M.; Graziani, G.; Gambardella, A.; Berni, M.; Russo, A.; Cannillo, V. Pulsed electron deposition of nanostructured bioactive glass coatings for biomedical applications. Ceram. Int. 2017, 43, 15862-15867. [CrossRef]

79. Vafa, H.M.; Johansson, D.; Wallen, H.; Sanchez, J. Improved ex vivo blood compatibility of central venous catheter with noble metal alloy coating. J. Biomed. Mater. Res. B Appl. Biomater. 2016, 104, 1359-1365. [CrossRef] [PubMed]

80. Veerachamy, S.; Yarlagadda, T.; Manivasagam, G.; Yarlagadda, P.K. Bacterial adherence and biofilm formation on medical implants: A review. Proc. Inst. Mech. Eng. H 2014, 228, 1083-1099. [CrossRef] [PubMed]

81. Zilberman, M.; Elsner, J.J. Antibiotic-eluting medical devices for various applications. J. Control. Release 2008, 130, 202-215. [CrossRef] [PubMed]

82. Alt, V. Antimicrobial coated implants in trauma and orthopaedics-A clinical review and risk-benefit analysis. Injury 2017, 48, 599-607. [CrossRef]

83. Blaker, J.J.; Nazhat, S.N.; Boccaccini, A.R. Development and characterisation of silver-doped bioactive glass-coated sutures for tissue engineering and wound healing applications. Biomaterials 2004, 25, 1319-1329. [CrossRef]

84. Branemark, P. Tissue-Integrated Prostheses. Osseointegration in Clinical Dentistry. In Introduction to Osseointegration; Branemark, P.I., Zarb, C., Albrektsson, T., Eds.; Quintessence Publishing Co.: Chicago, IL, USA, 1985; pp. 11-76.

85. Raphel, J.; Holodniy, M.; Goodman, S.B.; Heilshorn, S.C. Multifunctional coatings to simultaneously promote osseointegration and prevent infection of orthopaedic implants. Biomaterials 2016, 84, 301-314. [CrossRef]

86. Xie, C.M.; Lu, X.; Wang, K.F.; Meng, F.Z.; Jiang, O.; Zhang, H.P.; Zhi, W.; Fang, L.M. Silver nanoparticles and growth factors incorporated hydroxyapatite coatings on metallic implant surfaces for enhancement of osteoinductivity and antibacterial properties. ACS Appl. Mater. Interfaces 2014, 6, 8580-8589. [CrossRef]

87. Kolmas, J.; Groszyk, E.; Kwiatkowska-Różycka, D. Substituted hydroxyapatites with antibacterial properties. Biomed. Res. Int. 2014, 2014, 1-15. [CrossRef]

88. Melaiye, A.; Youngs, W.J. Silver and its application as an antimicrobial agent. Expert Opin. Ther. Pat. 2005, 15, 125-130. [CrossRef]

89. Galdiero, S.; Falanga, A.; Vitiello, M.; Cantisani, M.; Marra, M.; Galdiero, M. Silver nanoparticles as potential antiviral agents. Molecules 2011, 16, 8894-8918. [CrossRef]

90. Lansdown, A.B.G. A pharmacological and toxicological profile of Ag as an antimicrobial agent in medical devices. Adv. Phar. Sci. 2010, 2010, 1-16. [CrossRef] [PubMed]

91. Pauksch, L.; Hartmann, S.; Rohnk, M.; Szalay, G.; Alt, V.; Schnettler, R.; Lips, K.S. Biocompatibility of Ag nanoparticles and Ag ions in primary human mesenchymal stem cells and osteoblasts. Acta Biomater. 2014, 10, 439-449. [CrossRef] [PubMed]

92. Le Ouay, B.; Stellacci, F. Antibacterial activity of Ag nanoparticles: A surface science insight. Nano Today 2015, 10, 339-354. [CrossRef]

93. Gambardella, A.; Berni, M.; Graziani, G.; Kovtun, A.; Liscio, A.; Russo, A.; Visani, A.; Bianchi, M. Nanostructured Ag thin films deposited by pulsed electron ablation. Appl. Surf. Sci. 2019, 475, 917-925. [CrossRef]

94. Li, B.; Webster, T. Orthopedic Biomaterials: Advances and Applications; Springer: Berlin, Germany, 2018.

95. Ficai, A.; Grumezescu, A. Nanostructures for Antimicrobial Therapy, 1st ed.; Elsevier: Amsterdam, The Netherlands, 2017.

96. Thompson, C.V. Solid-state dewetting of thin films. Annu. Rev. Mater. Res. 2012, 42, 399-434. [CrossRef]

97. Jacquet, P.; Podor, R.; Ravaux, J.; Teisseire, J.; Gozhyk, I.; Jupille, J.; Lazzari, R. Grain growth: The key to understand solid-state dewetting of silver thin films. Scripta Mater. 2016, 115, 128-132. [CrossRef]

98. Leroy, F.; Borowik, L.; Cheynis, F.; Almadori, Y.; Curiotto, S.; Trautmann, M.; Barbè, J.C.; Muller, P. How to control solid state dewetting: A short review. Surf. Sci. Rep. 2016, 71, 391-409. [CrossRef]

99. Berni, M.; Carrano, I.; Kovtun, A.; Russo, A.; Visani, A.; Dionigi, C.; Liscio, A.; Valle, F.; Gambardella, F. Monitoring morphological and chemical properties during silver solid-state dewetting. Appl. Surf. Sci. 2019, 498, 1-8. [CrossRef]

100. Taylor, E.N.; Webster, T.J. The use of superparamagnetic nanoparticles for prosthetic biofilm prevention. Int. J. Nanomed. 2009, 4, 145-152. 
101. Gambardella, A.; Bianchi, M.; Kaciulis, S.; Mezzi, A.; Brucale, M.; Cavallini, M.; Herrmannsdoerfer, T.; Chanda, G.; Uhlarz, M.; Cellini, A.; et al. Magnetic hydroxyapatite coatings as a new tool in medicine: A scanning probe investigation. Mater. Sci. Eng. C 2016, 62, 444-449. [CrossRef]

102. Amberg, M.; Grieder, K.; Barbadoro, P.; Heuberger, M.; Hegemann, D. Electromechanical behavior of nanoscale silver coatings on PET fibers. Plasma Process. Polym. 2008, 5, 874-880. [CrossRef]

103. Atwa, Y.; Maheshwari, N.; Goldthorpe, I.A. Silver nanowire coated threads for electrically conductive textiles. J. Mater. Chem. C 2015, 3, 3908-3912. [CrossRef]

104. Ortolani, A.; Bianchi, M.; Mosca, M.; Caravelli, S.; Fuiano, M.; Marcacci, M.; Russo, A. The prospective opportunities offered by magnetic scaffolds for bone tissue engineering: A review. Joints 2016, 4, 228-235. [CrossRef] [PubMed]

105. Vandrovcova, M.; Douglasb, T.E.L.; Mróz, W.; Musial, O.; Schaubroeck, D.; Budner, B.; Syroka, R.; Dubruel, P.; Bacakova, L. Pulsed laser deposition of magnesium-doped calcium phosphate coatings on porous polycaprolactone scaffolds produced by rapid prototyping. Mater. Lett. 2015, 148, 178-183. [CrossRef]

106. Carli, S.; Bianchi, M.; Zucchini, E.; Di Lauro, M.; Prato, M.; Murgia, M.; Fadiga, L.; Biscarini, F. Electrodeposited PEDOT: Nafion composite for neural recording and stimulation. Adv. Healthc. Mater. 2019, 8, 1900765-1900775. [CrossRef]

107. Di Lauro, M.; Benaglia, S.; Berto, M.; Bortolotti, C.A.; Zoli, M.; Biscarini, F. Exploiting interfacial phenomena in organic bioelectronics: Conformable devices for bidirectional communication with living systems. Colloids Surf. B Biointerfaces 2018, 168, 143-147. [CrossRef]

(C) 2019 by the authors. Licensee MDPI, Basel, Switzerland. This article is an open access article distributed under the terms and conditions of the Creative Commons Attribution (CC BY) license (http://creativecommons.org/licenses/by/4.0/). 